\title{
A comparative study between fine needle aspiration cytology findings and histopathological report of major salivary gland neoplasm in a tertiary hospital of Bangladesh
}

\author{
Huq AHMZ1, Aktaruzzaman $\mathrm{M}^{2}$, Habib $\mathrm{MA}^{3}$, Islam MS ${ }^{4}$, Amin $\mathrm{ASA}^{1}$ \\ ${ }^{I}$ Deptt. of ENT, Bangabandhu Sheikh Mujib Medical University, Dhaka, ${ }^{2}$ Upazilla Health Complex, \\ Hazigong, Chandpur, ${ }^{3}$ Deptt. of ENT, Rangpur Medical College Hospital, Rangpur, ${ }^{4}$ Upazilla Health \\ Complex, Nawabgong, Dhaka. Email: zhuq_sach@yahoo.com
}

\begin{abstract}
Salivary gland tumours are relatively uncommon and most of the tumours arise from parotid gland. Fine needle aspiration cytology (FNAC) is advised preoperatively as diagnostic tool but sometimes found to shown both false positive and false negative results. This study was aimed to find out distribution of neoplasm of major salivary glands and also to explore the sensitivity and specificity of FNAC. The present cross sectional study was done in the Dept. of Otolaryngology Head and Neck Surgery, BSMMU from January 2007 to December 2008. A total number of 60 gender-matched patients with major salivary neoplasm, confirmed by FNAC, were recruited in the study. Operated salivary gland specimens were sent for histopathological examination, histopathological findings were compared. Overall male to female ratio was 1:1. Out of 60 cases, 47 (78.3\%) patients had parotid and $13(21.7 \%)$ patients submandibular gland neoplasm. Male to female ratio for parotid tumour was 1:1.1 and for submandibular 1.6:1. Mean age of the patients was 44.5 with range of 14-85 years. Of the total 60 cases $47(78.3 \%)$ were benign and $13(21.7 \%)$ malignant. Out of 47 parotid tumour $85.1 \%$ were benign and $14.9 \%$ malignant. Among the parotid tumour $97 \%$ were superficial lobe and $3.0 \%$ deep lobe. In case of submandibular gland $53.84 \%$ were benign and $46.15 \%$ tumour malignant. According to the sides of involvement, $25(53.2 \%)$ cases of parotid neoplasm tumour were in the left and $22(46.8 \%)$ the right. In submandibular gland the distribution was $7(53.8 \%)$ and $6(46.16 \%)$ respectively. Statistically incidence of parotid tumour was significantly higher than submandibular tumour $(\mathrm{p}<0.05)$. Out of 60 cases in 56 (93.3\%) preoperative FNAC and postoperative histopathological findings were same. There was $1.7 \%$ false positive and $5 \%$ were false negative results. Sensitivity, specificity of FNAC were $80 \%$ and $97.8 \%$ respectively. Positive predictive value was $92.3 \%$ and negative predictive $93.6 \%$ for FNAC.FNAC though cheap and safe but its diagnostic accuracy was $93.3 \%$.Histopathologial examination remained to be of value for diagnostic confirmation of major salivary gland neoplasm.
\end{abstract}

\section{Introduction}

Neoplasms that arise in the salivary glands are relatively rare, yet they represent a wide variety of both benign and malignant histologic subtypes. It constitutes about $10 \%$ of all head neck neoplasms which, however, is $3 \%$ of all neoplasms in the body ${ }^{1}$. Incidence of salivary gland neoplasm in USA found to be about 3-4\% of all neoplasm of the head and neck regions ${ }^{2}$. Worldwide incidence of salivary gland neoplasm, however, reported to be between 0.4 to 13.5 cases per $100,000^{3}$.

Salivary gland tumours are mainly benign in nature,.Carcinoma of the salivary gland also uncommon accounting for less than 1 percent of all head and neck malignant neoplasm. And among malignant cases mucoepidermoid carcinoma was the commonest $(39.7 \%)^{\mathbf{4}}$ by histopathological evaluation. Patients with benign salivary gland neoplasm reported to relatively younger compared to those with malignant cases; median age 51 vs 58 years. It was also demonstrated that tumours arise from parotid gland is $75 \%$, submandibular gland $16 \%$, minor salivary gland $8 \%$ and sublingual gland $1 \%$ cases. Moreover, benign tumours found to be pleomorphic adenoma and mostly of parotid gland origin. On the contrary adenoid cystic was the most common type of malignant cases and originated from submandibular and minor salivary glands ${ }^{\mathbf{5}}$. However, most benign tumours were pleomorphic adenoma, adenolymphoma and most malignant was mucoepidermoid carcinoma ${ }^{6}$.

Fine needle aspiration of salivary gland lesion may provide preoperative tissue diagnosis. Sismanis and colleague in 1981 reported, 74\% overall accuracy rate based on a series of 51 fine needle aspirations. The advantages of fine needle aspiration include its safety, cost and speed ${ }^{7}$. Fine needle aspiration cytology (FNAC) is being increasingly used in the diagnosis of the salivary gland lesions. Cytopathological correlation available of which diagnostic accuracy was $87.5 \%$. $3.12 \%$ false positive and $9.37 \%$ false negative reports. Thus fine 
needle aspiration cytology is a useful diagnostic tool in evaluating neoplastic lesions of the salivary glands 8 .

For salivary gland neoplasm, agreement between histotype determination using FNAC and final histological diagnosis was $79 \%$, specificity was $100 \%$, sensitivity was $83 \%$ and diagnostic accuracy was $97 \%{ }^{9}$

Hypothesis: Neoplasm within the major salivary glands predominantly involves the parotid and there are both false positive and false negative results in FNAC test.

Objectives: To find out the topographical distribution and types of neoplasm of the major salivary glands and also compare the preoperative FNAC with postoperative histopathological findings of the study subjects.

\section{Materials and Methods}

Study Design - A cross sectional study was undertaken in the Department of OtolaryngologyHead and Neck Surgery, BSMMU, Dhaka from January 2007 to December 2008.

Sample Size - Sixty subjects gender matched patients with major salivary gland neoplasm confirmed by FNAC were included.

Inclusion criteria- Patients of all age with major salivary glands neoplasm and confirmed by FNAC and completion of surgery.

Exclusion criteria- Inflammatory, autoimmune and granulomatous swelling of major salivary glands.

Data collection method- Written informed consent was taken from all the respondents. Data were collected by reviewing medical records.

Sample collection- Preoperative FNAC and postoperative histopathological report.

Analysis of data and result- Results were expressed as mean $\pm \mathrm{SD}$ and number (percentage) where applicable. Data were analyzed by using standard statistical program. Results were evaluated by using appropriate tests ( $Z$ test and $\chi^{2}$ test). $P$ value $<0.05$ was taken as level of significance.

\section{Results}

During the study period among 2554 different surgery, 67 (2.6\%) surgeries were done for major salivary gland neoplasm, $2487(97.4 \%)$ surgeries were done for others. Difference between operation performed for other then salivary glands neoplasm were statistically significant $(\mathrm{p}<0.001)$. A total of 60 gender matched patients with major salivary gland neoplasm were recruited in the study. Study subjects were between 14-85 years with mean age of 44.5 years. Distribution of patients in different age cluster was shown in table I. Proportion of patients in 4th, 5th and 6th decade was 20\%, 36.7\% and $23.3 \%$ respectively which constituted $80 \%$ of cases.

Of the 60 subjects $47(78.3 \%)$ had parotid and 13 (21.7\%) submandibular gland neoplasm $[\mathrm{Z}=0.516$; $\mathrm{p}>0.05]$. There was no case involving sublingual gland. Among the 47 subjects with parotid neoplasm 22 were male and 25 female having male female ration 1:1.3 On the other hand among 13 subjects with submandibular neoplasm male female distribution was 8 and 5 respectively and ratio 1.6:1. Within parotid tumours $22(36.7 \%)$ involved the right side and $25(41.7 \%)$ left sided. Submandibular tumours the distribution was 7 $(11.7 \%)$ and $6(10.0 \%)$ respectively (Table II).

In FNAC,among the parotid neoplasm $40(85.1 \%)$ were benign and $7(14.9 \%)$ malignant. In case of submandibular neoplasm the distribution was 7 $(53.8 \%)$ and $6(46.2 \%)$ respectively (Figure I). Among all the subjects distribution of benign and malignant cases were (parotid and submandibular) $47(78.3 \%)$ and $13(21.7 \%)$ respectively. Benign cases were significantly higher $(p<0.001)$.Within benign parotid tumour Pleomorphic adenoma was $82.5 \%$ and next frequent type was Warthin's tumour $(12.5 \%)$. Of the malignant parotid tumours mucoepidermoid carcinoma was $57.1 \%$ (Table III) was commonest, Adenoid cystic carcinoma, Adenocarcinoma and Squamous cell carcinoma were same frequency(14.3\%). Among benign submandibular gland tumour Pleomorphic adenoma was $57.1 \%$.Moreover Warthin's tumour and Schwannoma were $28.6 \%$ and $14.3 \%$ respectively. Of the malignant submandibular cases $50 \%$ was adenoid cyst carcinoma, $33.3 \%$ mucoepidermal and $16.7 \%$ were adenocarcinoma (Table III).

Histopathological findings of the salivary gland neoplasm were shown in table IV. Out of 47 parotid neoplasm 39 turned out to be benign and rest 8 malignant. Among the benign cases $82.0 \%$ were Pleomorphic adenoma and 12.8\% Warthin's tumour. Of the malignant parotid tumours $62.5 \%$ was mucoepidermoid carcinoma and $12.5 \%$ for adenoid cystic carcinoma, adeno-carcinoma and sqamous cell carcinoma. In case of 13 submandibular glands 6 were benign and 7 malignant. Among benign cases 50.0\% were Pleomorphic followed by Warthin's tumour and schwannoma $33.3 \%$ and $16.7 \%$ respectively. Of the 7 malignant submandibular cases $57.1 \%$ were adenoid cyst carcinoma followed by $28.6 \%$ mucoepidermoid carcinoma and $14.3 \%$ adenocarcinoma respectively. 
Among 33 parotid pleomorphic adenoma cases most were involved in the superficial lobe rather than deep lobe $(97 \%$ vs $3 \%$; $\mathrm{p}<0.01)$.

Table I: Distribution of patients with salivary gland neoplasm on the basis of age (yrs) groups

\begin{tabular}{ccc}
\hline Age groups & Number of case & Percentage \\
\hline $0-10$ & 0 & - \\
$11-20$ & 2 & 3.3 \\
$21-30$ & 6 & 10.0 \\
$31-40$ & 12 & 20.0 \\
$41-50$ & 22 & 36.7 \\
$51-60$ & 14 & 23.3 \\
$61-70$ & 3 & 5.0 \\
$71-80$ & 0 & - \\
$81-90$ & 1 & 1.6 \\
\hline Total & 60 & $100 \%$ \\
\hline
\end{tabular}

Table II: Distribution of the major salivary gland neoplasm of the study subjects $(n=60)$ on the basis of side of involvement

\begin{tabular}{lcc}
\hline Gland type & Side of involvement & $\mathrm{N}(\%)$ \\
\hline Parotid $(\mathrm{n}=47)$ & Right side & $22(36.7)$ \\
& Left side & $25(41.7)$ \\
Submandibular $(\mathrm{n}=13)$ & Right side & $6(10.0)$ \\
& Left side & $7(11.7)$ \\
\hline
\end{tabular}

Table III: Distribution of study subjects $(n=60)$ on the basis of FNAC report of major salivary neoplasm

\begin{tabular}{|c|c|c|c|c|}
\hline $\begin{array}{c}\text { Gland } \\
\text { involved }\end{array}$ & $\begin{array}{c}\text { Type of } \\
\text { neoplasm }\end{array}$ & Types & Number & $\begin{array}{c}\text { Percen } \\
\text { tage }\end{array}$ \\
\hline \multirow{8}{*}{$\begin{array}{l}\text { Parotid } \\
(\mathrm{n}=47)\end{array}$} & \multirow{4}{*}{$\begin{array}{l}\text { Benign } \\
(40)\end{array}$} & Pleomorphic adenoma & 33 & 82.5 \\
\hline & & Warthin's tumour & 5 & 12.5 \\
\hline & & Monomorphic adenoma & 1 & 2.5 \\
\hline & & Angioma & 1 & 2.5 \\
\hline & \multirow{4}{*}{$\begin{array}{l}\text { Malignant } \\
\text { (7) }\end{array}$} & $\begin{array}{l}\text { Mucoepidermoid } \\
\text { Carcinoma }\end{array}$ & 4 & 57.1 \\
\hline & & Adenoid cystic & 1 & 14.3 \\
\hline & & Adeno carcinoma & 1 & 14.3 \\
\hline & & Sqamous cell carcinoma & 1 & 14.3 \\
\hline \multirow{6}{*}{$\begin{array}{l}\text { Subman } \\
\text { dibular } \\
(n=13)\end{array}$} & \multirow{3}{*}{ Benign (7) } & Pleomorphic adenoma & 4 & 57.1 \\
\hline & & Warthin's tumour & 2 & 28.6 \\
\hline & & Schwannoma & 1 & 14.3 \\
\hline & \multirow{3}{*}{$\begin{array}{l}\text { Malignant } \\
\text { (6) }\end{array}$} & $\begin{array}{l}\text { Adenoid cystic } \\
\text { Carcinoma }\end{array}$ & 3 & 50.0 \\
\hline & & $\begin{array}{l}\text { Mueoepidermoid } \\
\text { Carcinoma }\end{array}$ & 2 & \\
\hline & & Adenocarcinoma & 1 & 16.7 \\
\hline
\end{tabular}

Table IV: Distribution of study subjects $(n=60)$ on the basis of histopathological report of major salivary neoplasm

\begin{tabular}{|c|c|c|c|c|}
\hline $\begin{array}{l}\text { Gland } \\
\text { involved }\end{array}$ & $\begin{array}{c}\text { Type of } \\
\text { neoplasm }\end{array}$ & Types & Number & $\begin{array}{l}\text { Percen- } \\
\text { tage }\end{array}$ \\
\hline \multirow{8}{*}{$\begin{array}{l}\text { Parotid } \\
(\mathrm{n}=47)\end{array}$} & \multirow{5}{*}{$\begin{array}{l}\text { Benign } \\
(39)\end{array}$} & Pleomorphic adenoma & 32 & 82.0 \\
\hline & & Warthin's tumour & 5 & 12.8 \\
\hline & & Monomorphic adenoma & 1 & 2.6 \\
\hline & & Lymphangioma & 1 & 2.6 \\
\hline & & $\begin{array}{l}\text { Mucoepidermoid } \\
\text { Carcinoma }\end{array}$ & 5 & 62.5 \\
\hline & \multirow{4}{*}{$\begin{array}{l}\text { Malignant } \\
\quad(08)\end{array}$} & Adenoid cystic Carcinoma & 1 & 12.5 \\
\hline & & Adeno carcinoma & 1 & 12.5 \\
\hline & & Squamous cell carcinoma & 1 & 12.5 \\
\hline \multirow{6}{*}{$\begin{array}{l}\text { Subman } \\
\text { dibular } \\
(n=13)\end{array}$} & & Pleomorphic adenoma & 3 & 50.5 \\
\hline & \multirow{3}{*}{$\begin{array}{l}\text { Benign } \\
(06)\end{array}$} & Warthin's tumour & 2 & 33.3 \\
\hline & & Schwannoma & 1 & 16.7 \\
\hline & & Adenoid cystic Carcinoma & 4 & 57.1 \\
\hline & \multirow[t]{2}{*}{$\begin{array}{l}\text { Malignant } \\
\quad(07)\end{array}$} & $\begin{array}{l}\text { Mueoepidermoid } \\
\text { Carcinoma }\end{array}$ & 2 & 28.6 \\
\hline & & Adenocarcinoma & 1 & 14.3 \\
\hline
\end{tabular}

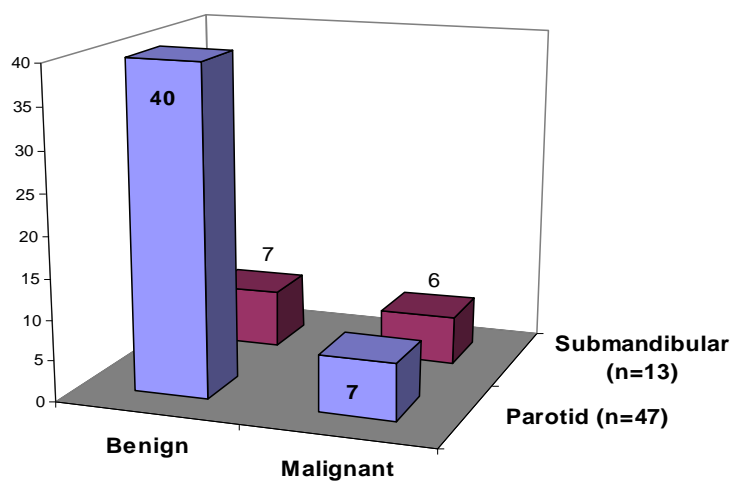

Fig. I: Distribution of subjects with major salivary (parotid and submandibular) glands on the basis of nature of neoplasm in FNAC.

\section{Discussion}

In the present series, 60 cases of major salivary gland neoplasm were studied with particular reference to found out the site distribution of neoplasm among the major salivary glands, diagnosed by FNAC and confirmation by histopathological examination. This series also compare the FNAC report with histopathological examination of resected specimen. The results obtained in this series were compared with other home and abroad studies.

Neoplasm of the parotid gland may occur at all ages, from early youth to advanced age ${ }^{\mathbf{1 0}}$. In our study the youngest patient was 14 years boy with pleomorphic adenoma and the oldest 85 years female with low grade mucoepidermoid carcinoma. Mean age was 44.5 years. This trend is consistent with one study which demonstrated mean age 44.1 years ${ }^{\mathbf{1 0}}$ but in other study it was 54 years ${ }^{5}$. Male and female were equally suffered from major salivary gland tumors ${ }^{4,10,11}$. In the present study for parotid tumour male-female ratio was $1: 1.13$ and submandibular 1.6:1. Nagarkar and his colleagues showed that $80 \%$ salivary gland tumours were of parotid gland and $15 \%$ submandibular gland of which $80 \%$ of parotid tumours and $50 \%$ of submandibular tumours were benign ${ }^{\mathbf{1 1}}$. In our series $78.3 \%$ tumour involved the parotid and $21.7 \%$ submandibular gland. In another study the frequency was shown to $75 \%$ for parotid gland, $16 \%$ submandibular and $8 \%$ minor salivary gland ${ }^{5}$. Our study had no sublingual gland involvement. The present study demonstrated consistency about frequency of parotid neoplasm among the major salivary glands. Tumour involved the parotid gland significantly higher than submandibular gland $\left(\chi^{2}=\right.$ $5.92, \mathrm{p}<0.05)$. It has been shown that $85 \%$ major salivary tumours are benign and $12 \%$ malignant $^{\mathbf{1 0}}$. Similarly in our study $85.1 \%$ of parotid tumours were benign and $14.9 \%$ tumour malignant. 
About $50 \%$ of submandibular gland neoplasms were found to be benign and $50 \%$ malignant. ${ }^{12}$ In the present study the benign and malignant proportion was $53.8 \%$ and $46.2 \%$ respectively. Although this trend was not different from the above mentioned but showed deviation from other in which benign submandibular tumour was $70 \%$ and malignant $30 \% \%^{6}$. Among 60 cases, benign tumours were significantly higher than malignant tumour (47 vs 13; p <0.001).

In case of major salivary gland tumour, there was no side predilection and also an equal distribution among right and left side $^{4}$. In our series among parotid and submandibular neoplasm, left side $53.3 \%$ were involved more than the right side $46.7 \%$.

Most benign tumours were located in the superficial lobe. The ratio of superficial to deep lobe was about $4: 1^{10}$. We have found $97 \%$ cases of pleomorphic adenoma were in the superficial lobe. Researcher showed patient are more often diagnosed to have benign tumour $(75 \%)$ than malignant $(25 \%)$ one $^{\mathbf{1 1}}$. The most common benign parotid tumour was pleomorphic adenoma (51\%) followed by Warthin's tumour (23\%) and the most common malignant tumour was mucoepidemioid carcinoma $(24.2 \%)$ followed by salivary duct carcinoma $15.2 \%$. In our study the common benign parotid tumour was pleomorphic adenoma $(82.0 \%)$ followed by Warthin's (12.8\%) and most common malignant tumour was mucoepidemoid $(57.1 \%)$ followed by adenoid cystic (14.3\%) and adenocarcinoma $(14.3 \%)$. This result differ from above study but correlate with others ${ }^{\mathbf{4}, 13}$.

Adenoid cystic carcinoma was the most common malignant tumour $(57.1 \%)$ followed by mucoepidemoid carcinoma $(28.6 \%)$. This result not correspond with the study where showed among benign submandibular tumours $66 \%$ were pleomorphic adenoma and among malignant submandibular tumours $53.8 \%$ were adenoid cystic carcinoma $^{12}$.

Fine needle aspiration cytology (FNAC) is being increasingly used in the diagnosis of salivary gland lesion. FNAC compared with histopathological findings showed diagnostic accuracy $87.5 \%$, false positive $3.12 \%$ and false negative reports $3.97 \%$. We found FNAC and histopathological findings comparable. It was observed that in 56 (93.3\%) cases preoperative FNAC and histoipathological findings were same. Only $4(6.7 \%)$ FNAC and histoipathological evaluation did not match. There was $1.7 \%$ false positive result and $5 \%$ were with false negative result.
The agreement between histotype determination using fine needle aspiration biopsy and final histological diagnosis was $79 \%$, specificity was $100 \%$, sensitivity was $83 \%$ and diagnostic accuracy was $97 \%$. Present study revealed sensitivity $80 \%$, specificity $97.8 \%$ and diagnostic accuracy was 93.3\%. Positive predictive value and negative predictive value of our study were $92.3 \%$ and $93.6 \%$ respectively. However, the study by Balakrishnen had showed that sensitivity and specificity were $84 \%$ and $79 \%$ respectively ${ }^{14}$.

Conclusions: FNAC has been proven as cheap, safe and quite accurate in the hands of experienced cytologist. Diagnostic accuracy of FNAC in the present study was $93.3 \%$ which suggested that FNAC may be routinely used in the work-up of all major salivary gland neoplasm. Since the result of the study revealed $5 \%$ false negativity and $1.7 \%$ false positivity.

\section{References}

1. Haroon AA, Ahmed K, Hanif A, Rahman SH, Fakir AY. Squamous cell carcinoma of submandibar gland in a young man. Bang J Otorhinolaryngology, 1996; 2: $75-77$.

2. Sharma D. Salivary gland tumours. 2006; [Online] [Accessed $9^{\text {th }}$ Aug 2007], [http://www.indiandctors. com

3. Auclair PL. Salivary gland neoplasm: General considerations. In: Ellis GL. Avelair PL, Gneepp DR, editors. Surgical Pathology of the Salivary gland, $1^{\text {st }}$ Ed. Philadelphia: WB Saunders Company, 1991; 135164.

4. Lee HN, Yadav BS, Ghoshal S. Treatment Outcome In Patients With Salivary Gland Tumors. Internet J Head Neck Surgery ISSN: 1937-819X. http://www.ispub. com/journal/the-internet-journal-of-head-and-necksurgery/volume-1-number-1/treatment-outcome-inpatients-with-salivary-gland-tumors.html [Accessed $31^{\text {st }}$ Aug. 2008],

5. Larrain D, Madrid A, Capdeville F, Ferrada C. Salivary gland tumors, Histopathological findings in 168 patients, Rev. chilena de cirugia 2005; 57: 373-378.

6. Hee CG, Perry CF. Fine- needle aspiration cytology of parotid tumours: is it useful? Aust. NZ J Surg, 2001; 71:345-348

7. Sismanis A, Merriam JM, Kline TS, Danis RK, Shapshay SM, Strong MS. Diagnosis of salivary gland tumour by Fine needle aspiration biopsy. Head Neck Surg 1981; 3: 482-489.

8. Pandit AA, Rernandes GC. Diagnosis of salivary gland tumors by FNAC, Indian J Cancer 1993; 31: 260-264. 
9. Aversa S, Ondolo C, Bollito E, Fadda G, Conticello S. Pre operative cytology in the management of parotid neoplasm, Am J Otolaryngol- Head and Neck Medicine and Surgery 2006; 27: 96-100.

10. Tsai HM, Lin CC, Huang CC, Huq CH, Tseng HC. Parotid tumours: a 10 year experience. Am J Otolaryngol Head and Neck Medicine and Surgery, 2008; 29: 94-100.

11. Nagarkar NM,Barsal S, Dass A, Singhal SK, Mohan H. Salivary gland tumors experience, Indian $J$ Otolaryngology and Head Neck surger 2004; 56: 3134.
12. Madrid A, Larrain D, Capdeville F, Ferrada C, Cumsille MA. Submandibular gland tumors: Experiencia del instituto Nacional del cancer, Reb. Chilena de cirugia, 2005; 57: 19-25.

13. Zbaren P, Schupbach J, Nuyens M, Hauster R. Carcinoma of the parotid gland. Am J Surgery, 2003; 186: $57-62$.

14. Balakrishnan $\mathrm{K}$, Castling $\mathrm{B}$, McMahon $\mathrm{J}$, Imrie $\mathrm{J}$, Feeley KM, Parker AJ, Johnston BA. Fine needle aspiration in the management of a parotid mass: a two centre retrospective study. Surgeon 2005; 3: 6772 . 